Keywords: Sickle cell anemia, Osteomyelitis, Salmonella typhi

Anahtar Sözcükler: Orak hücreli anemi, Osteomiyelit, Salmonella typhi

Conflict of Interest: The authors of this paper have no conflicts of interest, including specific financial interests, relationships, and/or affiliations relevant to the subject matter or materials included.

\section{References}

1. Almeida A, Roberts I. Bone involvement in sickle cell disease. Br J Haematol 2005;129:482-490.

2. Booth C, Inusa B, Obaro SK. Infection in sickle cell disease: a review. Int J Infect Dis 2010;14:e2-e12.

3. Atkins BL, Price EH, Tillyer L, Novelli V, Evans J. Salmonella osteomyelitis in sickle cell disease children in the East End of London. J Infect 1997;34:133-138.

4. Burnett MW, Bass JW, Cook BA. Etiology of osteomyelitis complicating sickle cell disease. Pediatrics 1998;101:296-297.

5. Barrett-Connor E. Bacterial infection and sickle cell anemia. An analysis of 250 infections in 166 patients and a review of the literature. Medicine (Baltimore) 1971;50:97-112.

\title{
Acquired Leukocyte Inclusion Bodies Resembling Döhle Bodies During Acute Cholangitis
}

\author{
Akut Kolanjit Seyrinde Lökositlerde Döhle Benzeri Edinsel İnklüzyonlar
}

\author{
Gökhan Özgür ${ }^{1}$, Musa Barış Aykan², Murat Yıldırım, Selim Sayın ${ }^{1}$, Ahmet Uygun ${ }^{3}$, Cengiz Beyan ${ }^{4}$ \\ ${ }^{1}$ Gülhane Training and Research Hospital, Department of Hematology, Ankara, Turkey \\ ${ }^{2}$ Health Sciences University, Gülhane Faculty of Medicine, Department of Internal Medicine, Ankara, Turkey \\ ${ }^{3}$ Health Sciences University, Gülhane Faculty of Medicine, Department of Gastroenterology, Ankara, Turkey \\ ${ }^{4}$ TOBB University of Economics and Technology Faculty of Medicine, Department of Internal Medicine, Ankara, Turkey
}

To the Editor,

A 66-year-old woman was admitted to the gastroenterology department with epigastric pain, nausea, and subicterus. Her complaints had begun $6 \mathrm{~h}$ earlier. Her abdomen was soft and flat, with localized tenderness on palpation in the right subcostal area. Laboratory studies revealed a white cell count of $17.9 \times 10^{9} / \mathrm{L}$, hemoglobin concentration of $14.4 \mathrm{~g} / \mathrm{dL}$, and platelet count of $48 \times 10^{9} / \mathrm{L}$, and they were notable for elevated serum cholestatic enzymes. The abdominal ultrasound was remarkable for cholangitis. The patient received broad-spectrum antibiotics. A peripheral blood smear examination, performed to evaluate thrombocytopenia, revealed the presence of blue intracytoplasmic inclusions in neutrophils (Figures 1A-C). On the $11^{\text {th }}$ day of treatment, her blood smear was examined once again and the Döhle body-like inclusions were resolved (Figure 1D).

May-Hegglin anomaly is an uncommon autosomal dominant abnormality characterized by large, basophilic inclusion bodies (resembling Döhle bodies) in neutrophils $[1,2]$. Döhle bodies

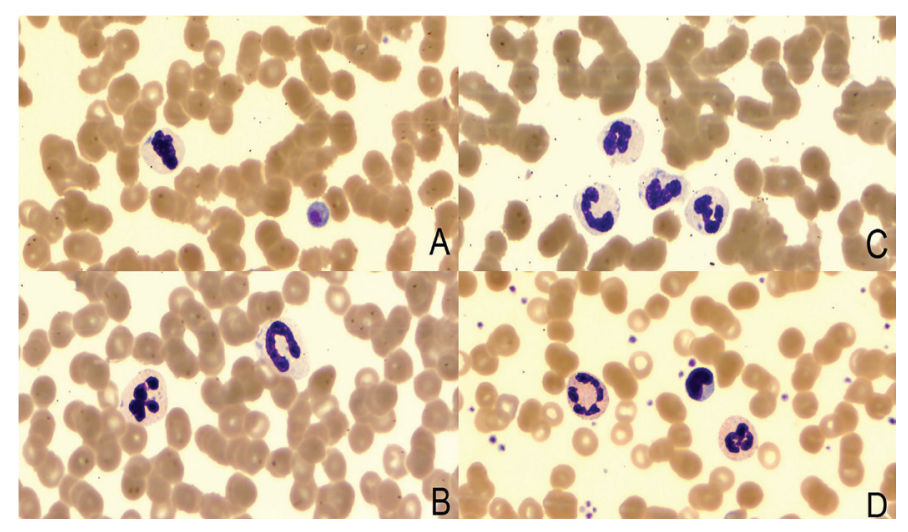

Figure 1. A) Inclusion bodies in neutrophils and macrothrombocyte; B), C) inclusion bodies in neutrophils; D) peripheral blood smear after treatment.

can be seen in bacterial infections. Hematologic findings of systemic diseases may be confused with hematological diseases such as May-Hegglin anomaly. We thought that the granules were Döhle bodies due to cholangitis. The disappearance of the inclusion bodies upon treatment is important in differential diagnosis. 
Keywords: Cholangitis, Döhle bodies, May-Hegglin anomaly

Anahtar Sözcükler: Döhle cisimciği, Kolanjit, May-Hegglin anomalisi

Conflict of Interest: The authors of this paper have no conflicts of interest, including specific financial interests, relationships, and/or affiliations relevant to the subject matter or materials included.

\section{References}

1. Saito H, Kunishima S. Historical hematology: May-Hegglin anomaly. Am J Hematol 2008;83:304-306.

2. Gülen $H$, Erbay $A$, Kazancı E, Vergin C. A rare familial thrombocytopenia: MayHegglin anomaly report of two cases and review of the literature. Turk J Haematol 2006;23:111-114.

\title{
Three Novel Calreticulin Mutations in Two Turkish Patients
}

\author{
İki Türk Hastada Üç Yeni Kalretikulin Mutasyonu
}

\author{
Veysel Sabri Hançer ${ }^{1}$, Hüseyin Tokgöz², Serkan Güvenç ${ }^{3}$ Ümran Çalışkan ${ }^{4}$, Murat Büyükdoğan ${ }^{1}$ \\ ${ }^{1}$ istinye University Faculty of Medicine, Department of Medical Genetics, Istanbul, Turkey \\ ${ }^{2}$ Selçuk University Meram Faculty of Medicine, Department of Pediatric Hematology, Konya, Turkey \\ ${ }^{3}$ Batman District State Hospital, Clinic of Hematology Batman, Turkey \\ ${ }^{4}$ Necmettin Erbakan University Meram Faculty of Medicine, Department of Pediatrics, Konya, Turkey
}

\section{To the Editor,}

Calreticulin (CALR) mutations were first identified exclusively in JAK2-MPL-negative essential thrombocythemia (ET) and primary myelofibrosis (PMF) at a rate of $60 \%-88 \%$, accounting for $1 / 4$ to $1 / 3$ of all patients with ET and PMF $[1,2,3]$. As of today, more than 55 different types of mutations have been reported. The two most common mutations accounting for $85 \%$ of mutated cases are either a 52-bp deletion (type 1 ; c. 1099_1150del; L367fs*46; 44\%$53 \%$ of cases) or a 5 -bp insertion (type 2; c.1154_1155insTTGTC; K385fs* $47 ; 32 \%-42 \%$ of cases). The remaining 15\% include various other infrequent mutations that are often unique or found in only a few patients $[4,5]$.

Here we present three CALR mutations in two patients with PMF and $E T$ that have not been reported before as shown in Figure 1. Known CALR mutations and BCR-ABL, JAK-2 V617F, and MPL $515 \mathrm{~L} / \mathrm{K}$ test results were found to be negative.

Patient 1: The patient was a 46-year-old man with low back pain. Magnetic resonance imaging scanning of the lumbosacral region revealed sacroiliitis on the left side and he was referred to a rheumatologist for further investigations. Anemia ( $\mathrm{Hb}$ : $10.8 \mathrm{~g} / \mathrm{dL})$ and thrombocytosis $\left(700 \times 10^{9} / \mathrm{L}\right)$ with a high lactate dehydrogenase level $(351 \mathrm{U} / \mathrm{L})$ were found in initial tests. The other tests for a possible rheumatologic disease, including

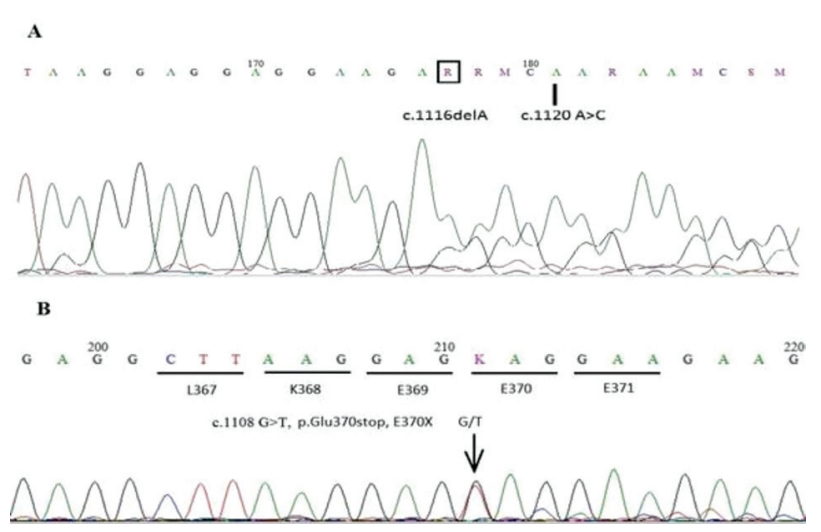

Figure 1. A) Electropherogram result of the primary myelofibrosis patient, B) electropherogram result of the essential thrombocythemia patient.

human leukocyte antigen-B27, were all negative when the patient was seen. Physical examination was almost normal with no sign of organomegaly. Spleen size was also normal in the abdominal ultrasound. The peripheral blood smear showed dacrocytes, occasional myelocytes (1\%), and metamyelocytes (1\%). The bone marrow biopsy showed diffuse grade 3-4 reticulin fibrosis with atypical proliferation of megakaryocytes and increased cellularity consistent with PMF.

Patient 2: A 9-year-old pediatric patient with thrombocytosis $\left(2800 \times 10^{9} / \mathrm{L}\right)$ was identified in a routine check-up. Physical 